\title{
Implementasi Penataan Administrasi Desa di Kecamatan Kumpeh Ulu Kabupaten Muaro Jambi
}

\author{
Netty, Irwandi dan Ratna Dewi \\ Fakultas Hukum, Universitas Jambi, Indonesia
}

\begin{abstract}
ABSTRAK
Penelitian ini dilatarbelakangi oleh Undang-Undang Pemerintahan Desa Nomor 6 Tahun 2014, selanjut dilaksanakan dengan Peraturan Pemerintah Nomor 72 Tahun 2005.. Pasal 2 ayat (1 dan 2) menentukan pembentukan desa dengan memperhatikan asal usul desa dan syarat yang sudah ditentukan. Menurut penelitian pendahuluan penulis, bahwa pelaksanaan administrasi desa pada pemerintah desa dalam wilayah Kecamatan Kumpeh Ulu Kabupaten Muaro Jambi dapat dikatakan belum sesuai dengan apa yang diamanatkan oleh peraturan yang berlaku karena yang hasilnya belum mengayomi masyarakat dalam melakukan suatu pembinaan di bidang yang dibutuhkan oleh masyarakat. Penelitian ini bertujuan untuk (1) mengetahui dan menganalisa. Implementasi penataan administrasi pemerintahan desa dan faktor apa dapat mempengaruhi pelaksanaan penataan administrasi pemerintahan desa Kegunaan penelitian ini dapat sebagai acuan dan masukan bagi pihak yang berkompeten khususnya dalam mengembangkan ilmu peneliti dalam mata kuliah hukum pemerintahan desa dan hukum administrasi desa, khususnya tentang fungsi pemerintah desa.(kepala desa) dalam penyelenggaraan penataan administrasi pemerintahan desa. Metode digunakan metode yuridis empiris (legal research) dengan spesifikasi penelitian bersifat deskriptif-analitis guna memperoleh gambaran tentang penataan administrasi desa dan pelaksanaan tugas kepala desa dalam penyelenggaraan administrasi pemerintahan desa. Pendekatan yang digunakan adalah pendekatan metode yuridis - normatif dan metode yuridis-empiris. Sumber data diambil dari data lapangan dan data sekunder dan primer. Terhadap data yang telah terkumpul dalam penelitian ini , kemudian diinventarisir dan diambil yang relevan, kemudian dianalisis dengan menggunakan metode deskriptif kualitatif Hasil yang diharapkan terlaksanaan administrasi pemerintahan desa yang sesuai dengan perundang-undangan dan kebutuhan masyarakat desa. Kesimpulan: penyelenggaraan administrasi pemerintahan desa belum berjalan karena ada beberapa kendala. Saran ,Pemerintah Desa dalam wilayah Kecamatan Kumpeh ulu harus meningkatkan pengetahuannya dan kesadaran sendiri untuk belajar dan memahami pelaksanaan administrasi desa demi majunya Desa yang dipimpinnya.. Luaran Hasil Penelitian: (1). Harapan terbentuknya administrasi desa yang sesuai dengan perundangundangan yang berlaku. (2) Publikasi Ilmiah pada Jurnal LPPM Universitas Jambi.
\end{abstract}

Kata Kunci: Implementasi, Penataan , Administrasi Desa.

\section{PENDAHULUAN}

Peraturan Pemerintah Nomor 72 Tahun 2005 Tentang Desa. Pasal 11 menyatakan bahwa: Pemerintahan Desa terdiri dari Pemerintahan Desa dan BPD. Kepala desa sebagai pimpinan penerintahan desa memepunyai kedudukan yang sangat penting karena kepala desa beserta perangkatnya yang menentukan terlaksana tidaknya jalannya pemerintahan, pelayanan kepada masyarakat dan pembangunan di desa. Oleh karena itu menyangkut tugas, wwwenang, dan kewajiban Kepala Desa diaturdalam peraturan pelaksana, Dalam pelaksanaan roda 
pemerintahan di tingkat pemerintahan terendah (desa) tidak terlepas dari dasar atau asas yang diatur dan terkandung dalam perundang-undangan yang mengatur wilayah yang paling rendah dalam wilayah negara disebut dengan pemerintahan terendah yang harus berdasar kan pada beberapa asas yang sudah ditentukan dalam asas- asas pemerintahan yang baik. Diantaranya adanya pertama "kepastian hukum," kedua " tertib pemerintahan", ketiga adanya "tertib kepentingan umumn terbuka, proposionalitas, profesional dan akuntabilitas

Kecamatan "Kumpeh Ulu” salah satu kecamatan dalam wilayah Kabupaten Muaro Jambi yang secara geografis wilayah "Kecamatan "Kumpeh Ulu berbatasan langsung dengan Kota Jambi berkembang cukup pesat akibat meningkatnya aktivitas ekonomi dan sosial masyarakat kota sehingga turut mempengaruhi kehidupan sosial masyarakat. Luas wilayah kecamatan Kumpeh Ulu adalah " $820 \mathrm{~km}^{2}$ dengan "penduduk "43.000 jiwa, dengan batas wilayah sebelah Utara Pusat Pemerintahan berlokasi di desa Pudak berjarak lebih kurang + "30 km" dari Pusat Pemerintahan., terdiri" dari 17 desa" sebagai berikut: pertama (1)Muaro Kumpeh, kedua(2) Pudak,ketiga (3) Kota Karang, keempat(4) Lopak Alai ke lima(5) Sakean, ke enam(6) Sungai Terap, ke tujuh(7) Sumber Jaya, ke delapan(8) Arang Arang, ke sembilan (9) Sipin Teluk Duren, sepuluh (10) Teluk Raya, sebels(11)Pemunduran,dua belas(12) Kasang Pudak, tiga belas (13) Kasang Lopak Alai empat belas(14) Solok lima belas (15) Ramin,enam belas (16) Kasang Pumpeh, tujuh belas(17) Tarikan.

Berdasarkan pengamatan pendahuluan penulis, melalui kegiatan penyuluhan hukum dalam beberapa tahun terakhir, bahwa pelaksanaan pemerintahan Desa "dalam wilayah Kecamatan Kumpeh Ulu Kabupaten Muaro Jambi" dapat dikatakan belum secara keseluruhan desa dapat melaksanakan tugas dan fungsinya sebagai pemerintahan desa sebagaimana yang diamanatkan oleh peraturan yang berlaku, karena hasilnya boleh dikatakan belum sesuai dengan apa yang dikendaki oleh aturan yang berlaku dan belum mengayomi masyarakat dalam melakukan suatu pembinaan baik di bidang yang dibutuhkan oleh masyarakat seperti sarana/prasarana keamananan, ketertiban dan perekonomian. Perubahan mendasar terjadi saat terbentuknya perundang-undanga ( Undang-Undang) yang mengatur tentang desa yang baru beserta peraturan pelaksanaanya. Hal ini nampak semakin terlihat dengan nyata bahwa tugas dan kewenangan yang dimiliki pemerinta desa dalam mengatur administrasi pemerintahan desa.

Berdasarkan hal di atas dapat dirumuskan masalah :

1. Bagaimana implementasi tugas kepala desa dalam penyelenggaraan administrasi pemerintahan desa di wilayah Kecamatan Kumpeh Ulu Kabupaten Muaro Jambi.?

2. Apa saja kendala dalam pelaksanaan tugas kepala desa dalam penyelenggaraan administrasi pemerintahan desa?

\section{TINJAUAN PUSTAKA}

Secara historis desa merupakan cikal bakal terbentuknya masyarakat politik dan pemerintahan di Indonesia jauh sebelum negara atau bangsa ini terbentuk. Struktur sosial sejenis desa, masyarakat adat dan lain sebagainya telah menjadi institusi sosial yang mempunyai posisi yang sangat penting. Kebanyakan desa di Indonesia baik yang berbentuk desa nelayan atau petani telah ada sejak ratusan atau bahkan ribuan tahun yang lalu. BN. Marbun mendefinisikan desa sebagai:

Satu daerah hukum yang ada sejak beberapa keturunan dan mepunyai ikatan kekeluargaan atau ikatan sosial yang hidup serta tinggal menetap di satu daerah tertentu dengan adat isitadat yang dijadikan landasan hukum dan mempunyai seorang pimpinan formil yaitu Kepala Desa. 
Pasal 1 angka (2) Undang-Undang Nomor 6 Tahun 2014 menyatakan Pemerintahan Desa adalah penyelenggaraan urusan Pemerintahan dan kepentingan masyarakat setempat dalam sistem pemerintahan Negara Kesatuan Republik Indonesia. Hal ini dilaksanakan oleh Pemerintah Desa dan Badan Permusyawaratan Desa setempat berdasarkan asal-usul dan adat istiadat setempat.

Bab III Pasal 33 dan 34 Peraturan Pemerintah Nomor 43 Tahun 2014 yaitu :

Kewenangan berdasarkan hak asal usul, paling sedikit terdiri atas; (2) Kewenangan local berskala desa, paling sedikit terdiri atas; (3) Kewenangan yang ditugaskan oleh pemerintah, pemerintah provinsi, pemerintah daerah kabupaten/kota; (4) Kewenangan lain yang ditugaskan oleh pemerintah, pemerintah provinsi, pemerintah kabupaten/kota sesuai dengan ketentuan peraturan perundang-undangan.

Menurut G. Kartasapoetra dkk yang menyatakan bahwa : Desa dapat berkembang karena para warganya mengutarakan asas-asas yang mempunyai nilai yang sangat universal yaitu :

a. Asas kegotongroyongan

b. Asas fungsi sosial atas milik dan manusia dalam masyarakat

c. Asas persetujuan sebagai dasar kekuasaan umum

d. Asas perwakilan dan permusyawaratan dalam sistem pemerintahanya

Hampir di seluruh tanah air tata kehidupan di desa-desa mempunyai persamaan, yaitu dengan asas-asas yang dimilikinya seperti di atas, para warga desa dapat menciptakan dan melangsungkan pemerintahannya dengan kemampuan para warga desanya itu sendiri. Dengan demikian dapat dikatakan bahwa setiap desa di tanah air telah memiliki sifat otonomi dalam arti mengatur atau mengurus rumah tangganya sendiri dengan kekuatan atau kemampuan sendiri.

Desa di dalam perkembangan sejarah ketatanegaraan dan tata pemerintahan sampai sekarang merupakan suatu wilayah yang ditempati oleh sejumlah penduduk yang mempunyai organisasi pemerintahan terendah langsung di bawah camat, telah memiliki hak menyelenggarakan rumah tangganya. Dengan demikian perkembangan dan pengembangan otonomi selanjutnya baik ke samping ke atas dan/atau ke bawah, sebagaimana dimaksud dalam Undang Undang Nomor 32 Tahun 2004, tetap dimungkinkan sesuai dengan kondisi politik, ekonomi, sosial dan budaya serta pertahanan dan keamanan nasional.

Pemerintah Desa adalah Kepala Desa dan perangkatnya, hal ini sebagaimana yang dinyatakan dalam peraturan perundang-undangan yang mengatur tentang desa. Dalam pelaksanaan tugasnya, pemerintah desa dibantu oleh perangkat desa. Kepala desa sebagai orang pertama yang mengemban tugas dan kewajiban yang berat karena ia adalah penyelengaraan dan penanggung jawab utama dibidang pemerintahan, pembangunan, kemasyarakatan dan urusan pemerintahan umum termasuk pembinaan ketenteraman dan ketertiban. Di samping itu kepala desa juga mengembangkan tugas membangun mental masyarakat desa baik dalam bentuk menumbuhkan maupun mengembangkan semangat membangun yang dijiwai oleh asas usaha bersama dan kekeluargaan. Dengan beratnya tugas kepala desa itu, maka dalam menjalankan tugas dan kewajibannya, kepala desa sebagai penanggung jawab utama di bidang pembangunan dibantu oleh perangkat desa.

C.S.T. Kansil yang menyatakan bahwa : Kepala desa diharapkan aksebilitas dan kapabilitasnya dalam melaksanakan tugas pemerintahan dan pembangunan dan juga sebagai pembina masyarakat, maka ia harus seorang pancasilais yang mempunyai dedikasi yang penuh terhadap amanat penderitaan rakyat. Sehingga dengan demikian seorang kepala desa akan mampu untuk :

a. Melaksanakan tugas-tugas pemerintahan dan pembangunan di desa

b. Menampung dan menyelesaikan segala permasalahan yang timbul di desa 
c. Membina hasil-hasil positif yang telah dicapai ke arah yang lebih baik.

Dengan keluarnya Undang-Undang pemerintahan desa yang baru, maka bertambah jelas tugas dan kewenangan yang diemban oleh pemerintah desa terkhusus dalam penataan administrasinya. Ini terbukti sebagaimana dinyatakan dalam Pasal 7 (tujuh) perundangundangan pemerintahan terendah tentang tugas, kewenangan, tujuan pemerintah desa. Yaitu:

(1) Pemerintah, Pemerintah Daerah Provinsi, dan Pemerintah Daerah Kabupaten/Kota dapat melakukan penataan Desa.

(2) Penataan sebagaimana dimaksud pada ayat (1) berdasarkan hasil evaluasi tingkat perkembangan Pemerintahan Desa sesuai dengan ketentuan peraturan perundangundangan.

(3) Penataan sebagaimana dimaksud pada ayat (1) bertujuan:

a. mewujudkan efektivitas penyelenggaraan Pemerintahan Desa;

b. mempercepat peningkatan kesejahteraan masyarakat Desa;

c. mempercepat peningkatan kualitas pelayanan publik;

d. meningkatkan kualitas tata kelola Pemerintahan Desa; dan

e. meningkatkan daya saing Desa.

(4) Penataan sebagaimana dimaksud pada ayat (1) meliputi:

a. pembentukan;

b. penghapusan;

c. penggabungan;

d. perubahan status; dan

f. penetapan Desa.

Keberhasilan penyelenggaraan pemerintahan desa. Terutama dalam pelaksanaan urusan pemerintahan dan pembangunan akan tergantung kepada perencanaan. Penyusunan perencanaan akan bersumber kepada data dan informasi. Berdasarkan Peraturan Menteri Dalam Negeri Nomor 32 Tahun 2006 tentang Pedoman Administrasi Desa yang telah diubah dengan Peraturan Menteri Dalam Negeri Nomor 43 Tahun 2014 ditetapkan ada beberapa jenis adminstrasi desa yang harus dilaksanakan oleh pemerintah desa dalam pelaksanaan roda pemerintahan desa.

\section{METODE PENELITIAN}

Penelitian ini merupakan penelitian hukum yuridis empiris. menurut Bambang Waluyo, peneliotian hukum empiris adalah penelitian hukum sosiologis yang dapat dilakukan melalui penelitian lapangan atau turun langsung menemui sasaran penelitin guna mendapatkan data primer yaitu data yang diperoleh langsung dari masyarakat atau sasaran penelitian sebagai sumber utamanya. Perolehan data primer dapat melalui wawancara atau pun penyebaran kuisioner. Di samping penelitian empiris, penelitian yuridis normatif juga diperlukan sebagai teori dan data pendukung. yuridis-empiris yakni melihat ketentuan dalam peraturan perundang-undangan dan prateknya di lapangan. Data di analisa. Populasi dalam penelitian ini adalah desa-desa dalam wilayah kecamatan Kumpeh Ulu, karena desa ini dilihat dari pengamatan sebelumnya yang dilakukan melalui penyuluhan hukum, sebagai desa yang merupakan ibukota kecamatan dan terletak ditengah-tengah dari ibu kota kecamatan. Data dianalisis dengan menggunakan metode deskriptif kualitatif. 


\section{HASIL DAN PEMBAHASAN}

Pelaksanaan administrasi pemerintahan desa di Desa Kasang Kumpeh Kecamatan Kumpeh Ulu Kabupaten Muaro Jambi berpedoman pada peruandang-undangan yang berlaku yaitu Peraturan Mentri Dalam Negeri Nomor 47 Tahun 2016 tentang Administrasi Desa. Tetapi dalam realisasinya disamping berpedoman kepada Permendagri tersebut di atas, Pemerintah desa Kasang Kumpeh Kecamatan Kumpeh Ulu Kabupaten Muaro Jambi berpedoman pada peraturan lain yang relevan dan yang dibutuhkankan serta berdasarkan juga kearifan lokal desa Kasang Kumpeh. Adapun buku register desa yang sudah terisi dan terlaksana di desa Kasang Kumpeh dibagi berdasarkan tugas pokok dan fungsi Perangkat Desa. Ini pada dasarnya dilaksanakan secara aplikasi tidak secara manual. Dalam penyelenggaraan administrasi pemerintahan desa di desa Kasang Kumpeh yang utama dilaksanakan adalah pembinaan administrasinya. Adapun tujuan dari pembinaan administrasi pemerintahan desa adalah:

1. untuk meningkatkan tertib administrasi pemerintahan desa;

2. mengidentifikasi dan memberikan solusi pemecahan masalah yang timbul dalam proses maupun penyelesaian administrasi desa.

3. Pembinaan administrasi desa Kasang Kumpeh meliputi :

a. Pembinaan Penyusunan Siklus Tahunan Desa;

b. Pembinaan Administrasi Keuangan Desa;

c. Pembinaan Pengelolaan Tanah Kas Desa; dan

d. Pembinaan Penyusunan dan Pengelolaan Alokasi Dana Desa

Pembinaan Siklus Tahunan Desa (STD) di Desa Kasang Kumpeh dilaksanakan untuk menjalankan amanat Peraturan Bupati tentang Siklus Tahunan Desa, dimana STD akan menjadi pedoman pemerintah desa dalam melaksanakan kegiatan selama satu tahun anggaran. Siklus Tahunan Desa dilaksanakan dengan jadwal.

Pembinaan Administrasi Keuangan Desa di Desa Kasang Kumpeh selama tahun 2019 sampai sekarang meliputi pembinaan:

1. Buku Anggaran Desa

2. Buku Kas Umum

3. Buku Kas Pembantu terdiri:

a. Buku Pembantu Pendapatan per-jenis pendapatan TKD.

b. Buku Pembantu Pendapatan atas Pungutan Desa.

c. Buku Pembantu lainnya yang diperlukan sesuai kebutuhan

Dan yang menjadi kendala dalam penyelenggaraan administrasi desa di Desa Kasang Kumpeh terlihat pada pembinaan pengelolaan tanah kas desa dan Pembinaan Penyusunan dan Pengelolaan Alokasi Dana Desa di Desa Kasang Kumpeh belum terlaksana sebagaimana mestinya. Dengan keluarnya undang-undang Nomor 06 Tahun 2014 tentang Desa, semakin memperkuat tugas dari pemerintah desa untuk menyelenggarakan pemerintahan desa. Terutama sekali dalam penataan administrasi pemerintahan desa. Pasal 7 Undang-Undang Nomor 06 Tahun 2014 menyatakan:

(1) Pemerintah, Pemerintah Daerah Provinsi, dan Pemerintah Daerah Kabupaten/Kota dapat melakukan penataan Desa.

(2) Penataan sebagaimana dimaksud pada ayat (1) berdasarkan hasil evaluasi tingkat perkembangan Pemerintahan Desa sesuai dengan ketentuan peraturan perundangundangan.

(3) Penataan sebagaimana dimaksud pada ayat (1) bertujuan:

a. mewujudkan efektivitas penyelenggaraan Pemerintahan Desa;

b. mempercepat peningkatan kesejahteraan masyarakat Desa; 

d. mempercepat peningkatan kualitas pelayanan publik;
e. meningkatkan kualitas tata kelola Pemerintahan Desa; dan
f. meningkatkan daya saing Desa.

\section{KESIMPULAN DAN SARAN}

\section{Kesimpulan}

1. Pelaksanaan tugas kepala desa dalam penyelenggaraan administrasi pemerintahan desa belum berjalan sebagaimana yang diharapkan oleh perundang-undangan.

2. Kendala yang ditemui dalam pelaksanaan administrasi pemerintahan desa disebabkan karena pendidikan dari aparat desa dan kurangnya pelatihan-pelatihan yang dilaksanakan oleh pemerintah kecamatan dan kabupaten untuk pemerintah desa terutama sekali dalam hal pengsisian buku administrasi baik secara aplikasi maupun manual.

\section{Saran}

1. Pemerintah Desa Kasang Kumpeh harus meningkatkan pengetahuannya tentang perundang-undangan yang mengatur pemerintahan desa, dan membaca, mengamati serta mempelajari pemerintah desa yang lebih maju dalam pelaksanaan administrasi pemerintahan desa.

2. Pemerintah Desa Kasang Kumpeh harus lebih meningkatkan kesadaran sendiri untuk belajar dan memahami pelaksanaan administrasi desa demi majunya Desa Kasang Kumpeh.

\section{DAFTAR PUSTAKA}

Astim Riyanto, Teori Negara Kesatuan, Yapemdo, Bandung, 2006.

Ateng Syafrudin, , Pasang Surut Otonomi Daerah, Bina Cipta, Bandung, 1985.

Bagir Manan dan Kuntana Magnar, Beberapa Masalah Hukum Tatanegara Indonesia,

Alumni, Bandung, 1993

Bayu Surianingrat, Organisasi Pemerintahan Wilayah / Daerah, Aksara Baru, Jakarta, 1980

Kansil C.S.T, Pokok-pokok Pemerintahan di Daerah, Aksara Baru, Jakarta, 1985.

-------------, Hukum Tata Pemerintahan Indonesia, Ghalia Indonesia, Jakarta, 1986.

Krishna D. Darumurti dan Umbu Rauta, Otonomi Daerah Perkembangan Pemikiran dan Pelaksanaan, Citra Aditya Bakti, Bandung, 2000.

Kuntana Magnar, Pokok-pokok Pemerintahan Daerah Otonom dan Wilayah Administratif, Armico, Bandung, 1983.

Lexy J Moleong, Metodologi Penelitian Kualitatif, PT Remaja Rosdakarya, Bandung, 1995

Miriam Budiardjo, Dasar-dasar Ilmu Politik, Gramedia, Jakarta, 1996

Soerjono Soekanto dan Sri Mamudji, Penelitian Hukum Normatif, suatu tinjauan singkat, CV Rajawali, Jakarta, 1985.

Sunaryati Hartono, , Penelitian Hukum Di Indonesia Pada Akhir Abad Ke-20, Alumni, Bandung, 2006.

UUD 1945

Tap MPR RI No. III/MPR/2000

UU Nomor. 32 Tahun 2004

UU Nomor. 12 Tahun 2008

UU Nomor 06 Tahun 2014

Peraturan Pemerintah Nomor 79 Tahun 2005Permendagri Nomor 16 Tahun 2000 